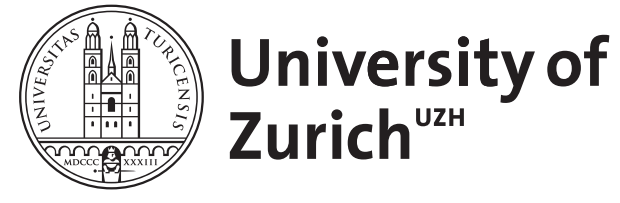
Archive

University of Zurich

University Library

Strickhofstrasse 39

CH-8057 Zurich

www.zora.uzh.ch

Year: 2021

The Languages and Linguistics of Mainland Southeast Asia

Edited by: Sidwell, Paul ; Jenny, Mathias

DOI: https://doi.org/10.1515/9783110558142

Posted at the Zurich Open Repository and Archive, University of Zurich

ZORA URL: https://doi.org/10.5167/uzh-205815

Edited Scientific Work

Published Version

Originally published at:

The Languages and Linguistics of Mainland Southeast Asia. Edited by: Sidwell, Paul; Jenny, Mathias (2021). Berlin: De Gruyter Mouton.

DOI: https://doi.org/10.1515/9783110558142 
The Languages and Linguistics of Mainland Southeast Asia WOL 8 


\section{The World of Linguistics}

Editor

Hans Henrich Hock

Volume 8 


\title{
The Languages and Linguistics of Mainland Southeast Asia
}

\author{
A Comprehensive Guide
}

Edited by

Paul Sidwell

Mathias Jenny 
ISBN 978-3-11-055606-3

e-ISBN (PDF) 978-3-11-055814-2

e-ISBN (EPUB) 978-3-11-055612-4

Library of Congress Control Number: 2021934687

Bibliographic information published by the Deutsche Nationalbibliothek The Deutsche Nationalbibliothek lists this publication in the Deutsche Nationalbibliografie; detailed bibliographic data are available on the Internet at http://dnb.d-nb.de.

(C) 2021 Walter de Gruyter GmbH, Berlin/Boston

Cover image: YODAPIX / iStock / Getty Images Plus

Typesetting: Dörlemann Satz, Lemförde

Printing and binding: $\mathrm{CPI}$ books $\mathrm{GmbH}$, Leck

www.degruyter.com 